\title{
Pomiar i próba oceny postaw przedsiębiorczych oraz zaangażowania studentów w proces doskonalenia kompetencji zawodowych - propozycje metodyczne
}

\author{
Beata Detyna \\ Instytut Przyrodniczo-Techniczny \\ Państwowa Wyższa Szkoła Zawodowa im. Angelusa Silesiusa w Watbrzychu
}

\begin{abstract}
Celem artykułu jest prezentacja propozycji metodycznej, dotyczącej pomiaru i oceny postaw przedsiębiorczych oraz zaangażowania studentów w proces doskonalenia kompetencji zawodowych. Przedstawiono w nim wyniki badania pilotażowego, przeprowadzonego wśród studentów Państwowej Wyższej Szkoły Zawodowej im. A. Silesiusa w Wałbrzychu, które posłużyły do weryfikacji opracowanego narzędzia - formularza ankietowego. Wyniki badania mogą stanowić inspirację dla osób przygotowujących programy kształcenia w szkołach wyższych (zwłaszcza na kierunkach o profilach praktycznych), tak aby odpowiadały na współczesne wyzwania rynku pracy oraz potrzeby studentów. Badanie ankietowe pozwoliło na prezentację graficzną wyników w postaci macierzy zaangażowania studentów w prace zespołowe oraz powstanie listy najczęstszych przyczyn braku ich zaangażowania zarówno w pracę grupową, jak i w rozwój własny.
\end{abstract}

Słowa kluczowe: postawy przedsiębiorcze, pomiar i ocena postaw przedsiębiorczych, studenci, kompetencje zawodowe, doskonalenie kompetencji zawodowych

\section{Wprowadzenie}

Wyniki przeprowadzonego wśród przedsiębiorców badania wskazują, że coraz częściej współczesny biznes ma problem z pozyskaniem odpowiedniego na dane stanowisko pracownika. I nie chodzi tu o tzw. twarde kompetencje (związane 
z posiadaniem konkretnej wiedzy i umiejętności niezbędnych w danym zawodzie). Relatywnie często pojawiają się opinie, że absolwenci szkół wyższych mają zbyt niskie kompetencje społeczne, $\mathrm{w}$ tym nie wykazują postaw przedsiębiorczych (Chrabąszcz, 2011; Marszałek, 2012; Detyna, 2013b; Górniak, 2015; Skała, 2015; Szerląg, 2015). W procesach rekrutacyjnych kluczowym kryterium coraz częściej staje się postawa kandydata - jego nastawienie, motywacja, chęć do samokształcenia, mobilność (jako skłonność do podejmowania nowych wyzwań), nieszablonowe myślenie, kreatywność, a także umiejętność radzenia sobie w stresujących sytuacjach ${ }^{1}$. Niezwykle istotne są także umiejętności współpracy w grupie, w tym rozwiązywania konfliktów (Roos, 2005; Gordon, 2009; Goleman, 2015). Z wielu badań wynika, że pracodawcy często mają trudności z zatrudnieniem osób zdolnych do podejmowania samodzielnych i szybkich decyzji, wykazujących się inicjatywą, zdolnych do przewidywania skutków swoich działań, a także wierzących we własne możliwości (Dąbrowska, Skowron, 2015). Wiele kompetencji znajdujących się na liście oczekiwanych na rynku pracy jest związanych z postawami przedsiębiorczymi ${ }^{2}$.

Osoba przedsiębiorcza to ktoś odpowiedzialny za swój rozwój, zaangażowany w pogłębianie i poszerzanie własnych kompetencji (zawodowych i osobistych), gotowy do podejmowania ryzyka, w swoim działaniu twórczy i pomysłowy, podejmujący przy tym samodzielne oraz często niestandardowe decyzje (Gordon, 2009; Detyna, 2016; Łuczka, Rembiasz, 2016). Modele zachowań przedsiębiorczych, jakie są obserwowane we współczesnych organizacjach, powinny być zatem włączane do programów kształcenia tak, aby zmniejszać obserwowaną i komunikowaną przez wielu przedsiębiorców lukę kompetencyjną między teorią a wiedzą praktyczną absolwentów (Fafaliou, 2012; Detyna, 2013a; Skała, 2015; Maresch i in., 2016). Cechy przedsiębiorcze powinny być przy tym kształtowane (również w toku studiów), ponieważ - jak twierdził P. Drucker (1992) - „przedsiębiorczość bazuje na ciągłym i niekończącym się procesie uczenia - uczenia poprzez działanie”. Jednocześnie warto podkreślić, że przedsiębiorczość jest jedną z kluczowych kompetencji wymienionych przez Komisję Europejską (w kontekście uczenia się przez całe życie). Stanowi ona bowiem podstawę rozwoju gospodarczego, a co się z tym wiąże - rozwoju społeczeństw (Marszałek, 2012).

1 Wyniki badań pochodzą z raportów: Narodowe Centrum Badań i Rozwoju (2014, s. 97-120); Badania rynku edukacji wyższej... (2013); Instytut Badań Edukacyjnych (2014, s. 64-69, 114-118); Patrz w przyszłość... (2015, s. 14-35); PARP (2016).

2 Raport pt. Start na rynku pracy (Fundacja Inicjatyw Młodzieżowych Nowoczesne Zarządzanie Biznesem, 2016) prezentuje wyniki badania wśród populacji 2000 polskich studentów. 


\section{Pomiar i ocena postaw przedsiębiorczych oraz zaangażowania studentów w proces doskonalenia kompetencji zawodowych - badanie}

\section{Cel i metodyka badania}

Celem artykułu jest prezentacja propozycji metodycznej, dotyczącej pomiaru i oceny postaw przedsiębiorczych oraz zaangażowania studentów w proces doskonalenia kompetencji zawodowych. Przedstawiono wyniki badania pilotażowego, przeprowadzonego wśród studentów Państwowej Wyższej Szkoły Zawodowej im. Angelusa Silesiusa (PWSZ AS) w Wałbrzychu, które posłużyły do weryfikacji opracowanego narzędzia - formularza ankietowego. Jako hipotezę badawczą przyjęto przypuszczenie, iż przeprowadzenie badania ankietowego zgodnie z proponowaną metodyką umożliwi przygotowanie stosownych rekomendacji, dotyczących programów kształcenia na uczelniach, które pragną aktywnie kształtować wśród swoich studentów postawy przedsiębiorcze, w tym świadomość potrzeby angażowania się w proces doskonalenia kompetencji zawodowych (w tym społecznych). Realizacja celu badania (weryfikacja przyjętej hipotezy) wymagała m.in. odpowiedzi na następujące pytania szczegółowe:

- jakie przejawy postaw przedsiębiorczych oraz angażowania się w proces doskonalenia kompetencji zawodowych można zaobserwować wśród studentów (podczas procesu kształcenia);

- w jaki sposób zaprojektować formularz ankietowy, aby odpowiedzi respondentów na pytania stały się cennym źródłem informacji, mogącym stanowić rekomendacje w procesie przygotowywania programów kształcenia - zgodnych z oczekiwaniami studentów i potencjalnych pracodawców.

Badanie przeprowadzono $\mathrm{w}$ semestrze zimowym roku akademickiego 2016/2017. Pilotażową grupę respondentów stanowiło 87 studentów studiów stacjonarnych (wszystkich roczników) kierunku Logistyka (41\% wszystkich studentów stacjonarnych na tym kierunku).

Strukturę respondentów przedstawiono w tabeli. 1.

Największą grupę respondentów stanowiły osoby w wieku 18-22 lat. Studenci I oraz II roku stanowili łącznie 53,8\%, natomiast III oraz IV roku - 46,2\%. Wśród badanych studentów większość to mężczyźni (65\%).

Przygotowany formularz został podzielony na trzy części. W pierwszej części badania ankietowego respondenci zaznaczali za pomocą znaku X stopień, w jakim zgadzają się z prezentowanymi w tabeli 2 dziesięcioma stwierdzeniami:

1) „Biorę odpowiedzialność za swój rozwój i przygotowanie do wykonania zawodu”; 
Tabela 1. Struktura respondentów badania ankietowego pt. Pomiar przedsiębiorczości wśród studentów logistyki - rok akademicki 2016/2017 (w \%)

\begin{tabular}{|c|c|c|c|c|c|c|c|}
\hline \multicolumn{2}{|c|}{ Wiek (w latach) } & \multicolumn{3}{|c|}{ Płeć } & \multicolumn{4}{c|}{ Rok studiów } \\
\hline $18-22$ & $23-27$ & K & M & I & II & III & IV \\
\hline 67,5 & 32,5 & 35 & 65 & 32,5 & 21,3 & 38,7 & 7,5 \\
\hline
\end{tabular}

Źródło: opracowanie własne.

2) „Jestem zaangażowany/a w rozwój swoich kompetencji zawodowych i osobistych - wykazuję inicjatywę w tym zakresie";

3) „Wykazuję postawę przedsiębiorczą związaną z podejmowaniem samodzielnych decyzji dotyczących dobrowolnego i świadomego podpisania umowy z konkretnym pracodawcą";

4) „Jestem świadomy/a roli doświadczenia zawodowego w kształtowaniu praktycznych umiejętności, niezbędnych przy podejmowaniu aktywności zarobkowej (zakładaniu i prowadzeniu działalności gospodarczej, a także znalezieniu i utrzymaniu wybranej przez siebie pracy)";

5) „Dla rozwoju swoich kompetencji jestem gotowy/a do podejmowania ryzyka (związanego np. z wyborem niewłaściwego pracodawcy, branży itp.)";

6) „Jestem świadomy/a, że uzyskane przeze mnie w toku studiów efekty kształcenia zależą przede wszystkim od mojego zaangażowania w proces poszerzania i pogłębiania wiedzy oraz umiejętności - dlatego też decyduję się na udział w dodatkowych formach kształcenia (np. kursach, szkoleniach, warsztatach, wykładach otwartych, wizytach studyjnych itp.)";

7) „Jestem zdania, że praca wykonywana przeze mnie w trakcie praktyk zawodowych (w ramach umowy z pracodawcą) pomoże mi w doskonaleniu umiejętności radzenia sobie w trudnych i stresujących sytuacjach - co ma kluczowe znaczenie np. podczas prowadzenia własnej działalności gospodarczej";

8) „Wykazuję kreatywność i niestandardowe podejście podczas realizowanych przez siebie zadań (w tym swojego rozwoju)";

9) „Jestem w grupie studentów, którzy dobrowolnie się zdecydowali na podjęcie dodatkowego wysiłku i pracy w konkretnej organizacji (równolegle realizując proces kształcenia na Uczelni)";

10) „Jestem zdania, że standardowy tok kształcenia może się okazać niewystarczający dla znalezienia interesującej mnie pracy (ewentualnie prowadzenia własnej działalności gospodarczej)".

Przyjęto przy tym skalę ocen od 1 do 5 (gdzie: 1 - zdecydowanie się nie zgadzam; 2 - raczej się nie zgadzam; 3 - nie wiem; 4 - raczej się zgadzam; 5 - zdecydowanie się zgadzam). 
Druga cześć formularza składała się z szesnastu następujących pytań, na które respondenci odpowiadali w sposób alternatywny („Tak” lub „Nie”):

- „Czy jesteś członkiem koła naukowego?”,

- „Czy planujesz być członkiem koła naukowego?”,

- „Czy działasz w Samorządzie Studenckim?”,

- „Czy planujesz działać w Samorządzie Studenckim?”,

- „Czy jesteś członkiem jakiejś organizacji poza Uczelnią, np. towarzystwa, zespołu itp.?”,

- „Czy działasz jako wolontariusz?”,

- „Czy systematycznie śledzisz oferty Biura Karier (informacje o szkoleniach, kursach, stażach itp.)?”,

- „Czy uczestniczyłeś/aś w szkoleniach i kursach organizowanych przez Biuro Karier Uczelni?”,

- "Czy uczestniczyłeś/aś w szkoleniach i kursach organizowanych poza Uczelnią?”,

- „Czy obecnie pracujesz?”,

- „Czy kiedyś już pracowałeś/aś?”,

- „Czy uczestniczyłeś/aś w organizowaniu np. konferencji, wycieczki (dla większej grupy osób)?”,

- „Czy planujesz w przyszłości założenie własnej działalności gospodarczej?”,

- „Czy prowadzisz własną działalność gospodarczą?”,

- Czy Uczelnia stwarza Ci możliwości do wykazania się przedsiębiorczością?”,

- „Czy, Twoim zdaniem, liczba 360 godzin obowiązkowych praktyk zawodowych na studiach o profilu praktycznym jest wystarczająca?”.

Ostatnia część formularza ankietowego miała formę otwartą - studenci w sposób opisowy odpowiadali na pięć pytań, w tym obliczali tzw. wskaźnik „osobistego wkładu" w realizowane prace zespołowe (Miller, 2010). Dla obliczenia wskaźników zaplanowano trzy kroki, w których poproszono respondentów o:

- ocenę wkładanej do pracy zespołowej (np. w grupie studentów, w pracy) energii (w skali od 1 do 10, gdzie 10 oznaczało maksymalne zaangażowanie) - krok 1 ,

- ocenę swojego nastawienia (w skali od 1 do 10, gdzie 10 oznaczało najbardziej pozytywne podejście) - krok 2 ,

- pomnożenie wskazanych dwóch liczb (maksymalna wartość wskaźnika „osobistego wkładu" to 100) - krok 3.

W części trzeciej formularza poproszono respondentów o odpowiedzi na następujące zagadnienia:

- „Podaj najczęstsze przyczyny swojego braku zaangażowania w pracę zespołową",

- „Podaj najczęstsze przyczyny swojego braku zaangażowania we własny rozwój", 
- „Jeśli planujesz prowadzenie własnej działalności gospodarczej, to krótko opisz, czym chciałbyś/chciałabyś się zajmować",

- „Co, Twoim zdaniem, powinna zapewnić Uczelnia, aby w wystarczającym stopniu kształtować wśród studentów postawy przedsiębiorcze".

\section{Wyniki badania}

W pierwszej części badania ankietowego respondenci zaznaczali za pomocą znaku X stopień, w jakim zgadzają się z prezentowanymi w tabeli 2 stwierdzeniami. W tabeli tej podano nie tylko rozkład poszczególnych odpowiedzi (przyjęto oceny: 1 - zdecydowanie się nie zgadzam; 2 - raczej się nie zgadzam; 3 - nie wiem; 4 - raczej się zgadzam; 5 - zdecydowanie się zgadzam), lecz także średni rezultat odpowiadający każdemu stwierdzeniu.

Tabela 2. Wyniki badań ankietowych - dla stwierdzeń podlegających samoocenie

\begin{tabular}{|c|c|c|c|c|c|c|}
\hline \multirow{2}{*}{ Stwierdzenia podlegające ocenie } & \multicolumn{5}{|c|}{ Odpowiedzi (w \%) } & \multirow{2}{*}{$\begin{array}{c}\text { Średnia } \\
\text { ocena }\end{array}$} \\
\hline & 1 & 2 & 3 & 4 & 5 & \\
\hline $\begin{array}{l}\text { 1. Biorę odpowiedzialność za swój rozwój } \\
\text { i przygotowanie do wykonania zawodu }\end{array}$ & 3,8 & 10,0 & 12,5 & 47,5 & 26,3 & 3,83 \\
\hline $\begin{array}{l}\text { 2. Jestem zaangażowany/a w rozwój swoich } \\
\text { kompetencji zawodowych i osobistych - } \\
\text { wykazuję inicjatywę w tym zakresie }\end{array}$ & 3,8 & 10,0 & 20,0 & 52,5 & 13,8 & 3,63 \\
\hline $\begin{array}{l}\text { 3. Wykazuję postawę przedsiębiorczą związaną } \\
\text { z podejmowaniem samodzielnych decyzji } \\
\text { dotyczących dobrowolnego i świadomego } \\
\text { podpisania umowy z konkretnym pracodawcą }\end{array}$ & 1,3 & 12,5 & 16,3 & 57,5 & 23,8 & 4,26 \\
\hline $\begin{array}{l}\text { 4. Jestem świadomy/a roli doświadczenia } \\
\text { zawodowego w kształtowaniu praktycznych } \\
\text { umiejętności, niezbędnych przy } \\
\text { podejmowaniu aktywności zarobkowej } \\
\text { (zakładaniu i prowadzeniu działalności } \\
\text { gospodarczej, a także znalezieniu } \\
\text { i utrzymaniu wybranej przez siebie pracy) }\end{array}$ & 5,0 & 3,8 & 13,8 & 36,3 & 41,3 & 4,05 \\
\hline $\begin{array}{l}\text { 5. Dla rozwoju swoich kompetencji jestem } \\
\text { gotowy/a do podejmowania ryzyka } \\
\text { (związanego np. z wyborem niewłaściwego } \\
\text { pracodawcy, branży itp.) }\end{array}$ & 1,3 & 20,0 & 12,5 & 45,0 & 21,3 & 3,65 \\
\hline
\end{tabular}




\begin{tabular}{|c|c|c|c|c|c|c|}
\hline \multirow{2}{*}{ Stwierdzenia podlegające ocenie } & \multicolumn{5}{|c|}{ Odpowiedzi (w \%) } & \multirow{2}{*}{$\begin{array}{c}\text { Średnia } \\
\text { ocena }\end{array}$} \\
\hline & 1 & 2 & 3 & 4 & 5 & \\
\hline $\begin{array}{l}\text { 6. Jestem świadomy/a, że uzyskane przeze mnie } \\
\text { w toku studiów efekty kształcenia zależą } \\
\text { przede wszystkim od mojego zaangażowania } \\
\text { w proces poszerzania i pogłębiania wiedzy } \\
\text { oraz umiejętności - dlatego też decyduję } \\
\text { się na udział w dodatkowych formach } \\
\text { kształcenia (np. kursach, szkoleniach, } \\
\text { warsztatach, wykładach otwartych, wizytach } \\
\text { studyjnych itp.) }\end{array}$ & 3,8 & 8,8 & 10,0 & 47,5 & 30,0 & 3,91 \\
\hline $\begin{array}{l}\text { 7. Jestem zdania, że praca wykonywana } \\
\text { przeze mnie w trakcie praktyk zawodowych } \\
\text { (w ramach umowy z pracodawcą) pomoże mi } \\
\text { w doskonaleniu umiejętności radzenia sobie } \\
\text { w trudnych i stresujących sytuacjach - co ma } \\
\text { kluczowe znaczenie np. podczas prowadzenia } \\
\text { własnej działalności gospodarczej }\end{array}$ & 7,5 & 15,0 & 16,3 & 33,8 & 27,5 & 3,59 \\
\hline $\begin{array}{l}\text { 8. Wykazuję kreatywność i niestandardowe } \\
\text { podejście podczas realizowanych przez siebie } \\
\text { zadań (w tym swojego rozwoju) }\end{array}$ & 1,3 & 7,5 & 20,0 & 57,5 & 12,5 & 3,83 \\
\hline $\begin{array}{l}\text { 9. Jestem w grupie studentów, którzy } \\
\text { dobrowolnie się zdecydowali na podjęcie } \\
\text { dodatkowego wysiłku i pracy w konkretnej } \\
\text { organizacji (równolegle realizując proces } \\
\text { kształcenia na Uczelni) }\end{array}$ & 16,3 & 22,5 & 17,5 & 22,5 & 21,3 & 3,10 \\
\hline $\begin{array}{l}\text { 10. Jestem zdania, że standardowy tok } \\
\text { kształcenia może się okazać niewystarczający } \\
\text { dla znalezienia interesującej mnie pracy } \\
\text { (ewentualnie prowadzenia własnej } \\
\text { działalności gospodarczej) }\end{array}$ & 5,0 & 6,3 & 22,5 & 28,8 & 37,5 & 3,88 \\
\hline
\end{tabular}

Uwaga: 1 - zdecydowanie się nie zgadzam; 2 - raczej się nie zgadzam; 3 - nie wiem; 4 - raczej się zgadzam; 5 zdecydowanie się zgadzam.

Źródło: opracowanie własne.

Zdecydowana większość respondentów (73,8\% - odpowiedzi 4-5) jest zdania, że bierze odpowiedzialność za swój rozwój i przygotowanie do wykonania zawodu. Jednak tylko nieliczna grupa $(13,8 \%)$ jest zaangażowana w rozwój swoich kompetencji zawodowych i osobistych (wykazując inicjatywę w tym zakresie). Wysoki poziom (odpowiedzi 4-5) świadomości roli doświadczenia zawodowego w kształtowaniu praktycznych umiejętności, niezbędnych przy podejmowaniu aktywności zarobkowej (w tym zakładaniu i prowadzeniu działalności gospodarczej, a także znalezieniu i utrzymaniu wybranej przez siebie pracy), wskazało $77,6 \%$ 
respondentów. Przy tym 33,8\% badanych w celu rozwoju swoich kompetencji nie jest raczej gotowa do podejmowania ryzyka (związanego np. z wyborem niewłaściwego pracodawcy, branży itp. (odpowiedzi 1-3). Większość studentów kierunku Logistyka (77,5\%) twierdzi, że uzyskane przez nich w toku studiów efekty kształcenia zależą przede wszystkim od osobistego zaangażowania w proces poszerzania i pogłębiania wiedzy oraz umiejętności, dlatego też decydują się na udział w dodatkowych formach kształcenia (np. szkoleniach, warsztatach, wizytach studyjnych itp.). Relatywnie liczna grupa respondentów (38,8\%) nie zgadza się ze stwierdzeniem, że praca wykonywana przez nich w trakcie praktyk zawodowych pomoże im w doskonaleniu umiejętności radzenia sobie w trudnych i stresujących sytuacjach (odpowiedzi 1-3). Wynik ten jest dosyć zaskakujący, biorąc pod uwagę fakt, iż większość studentów podkreśla znaczenie zajęć praktycznych w procesie kształcenia (rozwijania umiejętności). Być może na odpowiedzi wpływa przekonanie, że podczas praktyk zawodowych pracodawcy nie wymagają od studentów dużego zaangażowania (jest to jednak tylko przypuszczenie, które wymaga odpowiedniej weryfikacji). Tylko 12,5\% badanych w sposób zdecydowany zgadza się ze stwierdzeniem, iż wykazuje się kreatywnością i niestandardowym podejściem do realizowanych przez siebie zadań, w tym do swojego rozwoju (odpowiedź 5). Większość respondentów (56,3\%) nie decyduje się także na podjęcie podczas studiów dodatkowego wysiłku i pracy w konkretnej organizacji (odpowiedzi 1-3). Na pewien rozdźwięk między świadomością a konkretnymi działaniami (aktywnością) badanych studentów wskazują również odpowiedzi dotyczące ostatniego stwierdzenia. Zdecydowana większość $(66,3 \%)$ jest zdania, ze standardowy tok kształcenia może się okazać niewystarczający dla znalezienia interesującej pracy (ewentualnie prowadzenia własnej działalności gospodarczej).

W tabeli 3 przedstawiono wyniki badania pochodzące $z$ drugiej części formularza ankietowego, w którym poproszono respondentów o alternatywną („Tak” lub „Nie”) odpowiedź na szesnaście pytań.

Tabela 3. Wyniki badania ankietowego - rozkład odpowiedzi na pytania (w \%)

\begin{tabular}{|l|r|c|}
\hline \multicolumn{1}{|c|}{ Pytania } & Tak & Nie \\
\hline Czy jesteś członkiem koła naukowego? & 16,5 & 83,5 \\
\hline Czy planujesz być członkiem koła naukowego? & 27,5 & 72,5 \\
\hline Czy działasz w Samorządzie Studenckim? & 7,0 & 93,0 \\
\hline Czy planujesz działać w Samorządzie Studenckim? & 17,5 & 82,5 \\
\hline $\begin{array}{l}\text { Czy jesteś członkiem jakiejś organizacji poza Uczelnią, np. towarzystwa, } \\
\text { zespołu itp.? }\end{array}$ & 33,8 & 66,2 \\
\hline
\end{tabular}




\begin{tabular}{|l|c|c|}
\hline \multicolumn{1}{|c|}{ Pytania } & Tak & Nie \\
\hline Czy działasz jako wolontariusz? & 15,0 & 85,0 \\
\hline $\begin{array}{l}\text { Czy systematycznie śledzisz oferty Biura Karier (informacje o szkoleniach, } \\
\text { kursach, stażach itp.)? }\end{array}$ & 26,3 & 73,7 \\
\hline $\begin{array}{l}\text { Czy uczestniczyłeś/aś w szkoleniach i kursach organizowanych przez Biuro } \\
\text { Karier Uczelni? }\end{array}$ & 16,3 & 83,7 \\
\hline $\begin{array}{l}\text { Czy uczestniczyłeś/aś w szkoleniach i kursach organizowanych poza } \\
\text { Uczelnią? }\end{array}$ & 45,0 & 55,0 \\
\hline Czy obecnie pracujesz? & 27,5 & 72,5 \\
\hline Czy kiedyś już pracowałeś/aś? & 87,5 & 12,5 \\
\hline $\begin{array}{l}\text { Czy uczestniczyłeś/aś w organizowaniu np. konferencji, wycieczki (dla } \\
\text { większej grupy osób)? }\end{array}$ & 40,0 & 60,0 \\
\hline Czy planujesz w przyszłości założenie własnej działalności gospodarczej? & 66,3 & 33,8 \\
\hline Czy prowadzisz własną działalność gospodarczą? & 2,5 & 97,5 \\
\hline Czy Uczelnia stwarza Ci możliwości do wykazania się przedsiębiorczością? & 40,0 & 60,0 \\
\hline $\begin{array}{l}\text { Czy, Twoim zdaniem, liczba 360 godzin obowiązkowych praktyk } \\
\text { zawodowych na studiach o profilu praktycznym jest wystarczająca? }\end{array}$ & 65,0 & 35,0 \\
\hline
\end{tabular}

Źródło: opracowanie własne.

Na podkreślenie zasługuje fakt, że wśród respondentów znalazła się liczna grupa członków kół naukowych (16,5\%). W Instytucie Przyrodniczo-Technicznym (PWSZ AS), gdzie jest prowadzony m.in. kierunek Logistyka, prężnie działają dwa koła: Koło Naukowe Młodych Logistyków „Just in Time” oraz Studenckie Koło Naukowe Przedsiębiorczości „Eventus”. Znaczna część badanych (27,5\%) wskazała przy tym, że rozważa wstąpienie do koła naukowego. Relatywnie mniejsza grupa (7\%) zadeklarowała aktywną działalność w ramach Samorządu Studenckiego. Większość respondentów (66,2\%) jest członkiem organizacji poza uczelnią (np. towarzystwa, zespołu). Działalność natomiast w wolontariacie potwierdziło 15\% badanych studentów. Wyniki badań wskazują, że zdecydowana większość $(73,7 \%)$ nie śledzi systematycznie ofert Biura Karier (informacji o szkoleniach, kursach, stażach itp.). Osoby te nie mają zatem wiedzy na temat możliwości rozwoju, jakie stwarza im PWSZ AS. Swój udział w akcjach (szkoleniach, warsztatach, stażach) organizowanych przez Biuro Karier potwierdziło 16,3\% badanych studentów. Większość (55\%) nie uczestniczyła także w szkoleniach i kursach organizowanych poza Uczelnią. Aktywność na rynku pracy wskazało 27,5\% respondentów, co na studiach stacjonarnych wydaje się być wskaźnikiem wysokim. Na pytanie, czy kiedyś już pracowałeś/aś, twierdząco odpowiedziało aż 87,5\% studentów. Tak wysokie wyniki w tych dwóch aspektach wiążą się, być może (w pewnej części), z relatywnie trudną sytuacją materialną wielu respondentów (o czym mogą świadczyć 
wyniki innego badania przeprowadzonego przez autorkę) $)^{3}$. Większość studentów (60\%) nie ma doświadczenia w organizowaniu takich przedsięwzięć, jak konferencje, wycieczki (imprezy dla większej grupy osób). O ile chętnie biorą w nich udział, o tyle mniej entuzjastycznie podejmują konkretne działania organizacyjne.

Na podkreślenie zasługuje fakt, że większość badanych studentów $(66,3 \%)$ planuje w przyszłości założenie własnej działalności gospodarczej. Obecnie taką działalność prowadzi 2,5\% ankietowanych. Według 60\% respondentów Uczelnia nie stwarza wystarczających możliwości do wykazania się przedsiębiorczością. Zdecydowana większość (65\%) uważa, że liczba 360 godzin obowiązkowych praktyk zawodowych na studiach o profilu praktycznym jest wystarczająca. Zdaniem 35\% studentów kierunku Logistyka, korzystna byłaby dla nich realizacja praktyk w większej liczbie godzin.

W trzeciej część formularza ankietowego studenci w sposób opisowy odpowiadali na pytania oraz obliczali tzw. wskaźnik „osobistego wkładu” w realizowane prace zespołowe. Dla obliczenia indywidualnego wskaźnika każdy respondent oceniał: wkładaną do pracy zespołowej energię (w skali 1-10, gdzie 10 oznaczało maksymalne zaangażowanie) oraz swoje nastawienie (w skali 1-10, gdzie 10 oznaczało najbardziej pozytywne podejście). Pomnożenie dwóch wskazanych liczb pozwoliło na obliczenie wskaźnika, którego maksymalna wartość wynosi 100. Liczba ta oznacza maksymalny poziom zarówno zaangażowania (energii), jak i nastawienia (postaw) podczas realizacji prac zespołowych. Średnie wyniki z poszczególnych etapów obliczania wskaźnika przedstawiono w tabeli 4.

Tabela 4. Wyniki badań - średni wskaźnik „osobistego wkładu”

\begin{tabular}{|l|l|c|}
\hline \multicolumn{1}{|c|}{ Kolejność kroków } & \multicolumn{1}{|c|}{ Etapy obliczenia wskaźnika } & Wyniki średnie \\
\hline Krok 1 & ocena wkładanej do pracy zespołowej energii (1) & 6,81 \\
\hline Krok 2 & ocena swojego nastawienia (2) & 6,71 \\
\hline Krok 3 & obliczenie wskaźnika „osobistego wkładu” - (1) x (2) & 45,70 \\
\hline
\end{tabular}

Źródło: opracowanie własne.

Uzyskane wyniki średnie wskazują na to, że przeciętny respondent jest tzw. graczem (rysunek 1), poniewaź średnia ocena wkładanej do pracy zespołowej energii wyniosła 6,81, natomiast średnia ocena nastawienia studentów - 6,71. Współrzędne tych dwóch punktów zaznaczono na tzw. macierzy zaangażowania (rysunek 1). Macierz ta ma cztery pola (Miller, 2010):

3 Autorka przeprowadziła w 2014 r. wśród studentów kierunku Logistyka (PWSZ AS) badanie mające na celu analizę i ocenę postaw studentów wobec pracy (Detyna, 2014). 
1) „żywe mumie” - osoby charakteryzujące się niewielkim zarówno zaangażowaniem (energią), jak i nastawieniem (postawą), nie mają ochoty na większą aktywność i nie wierzą w jej sens;

2) „widzowie” - osoby, które cechuje pozytywna postawa, są zmotywowane, ale nie dysponują wystarczającą energią (siłą działania), ich zaangażowanie jest relatywnie małe, „przyglądają” się działaniom;

3) "cynicy” - są zaangażowani, działają, ale mają słabe nastawienie, często nie wierzą w powodzenie danego projektu, kontestują realizowane zadania;

4) "gracze" - osoby, których zarówno zaangażowanie, jak i postawa są na wysokim poziomie.

\section{Rysunek 1. Macierz zaangażowania respondentów w prace zespołowe}

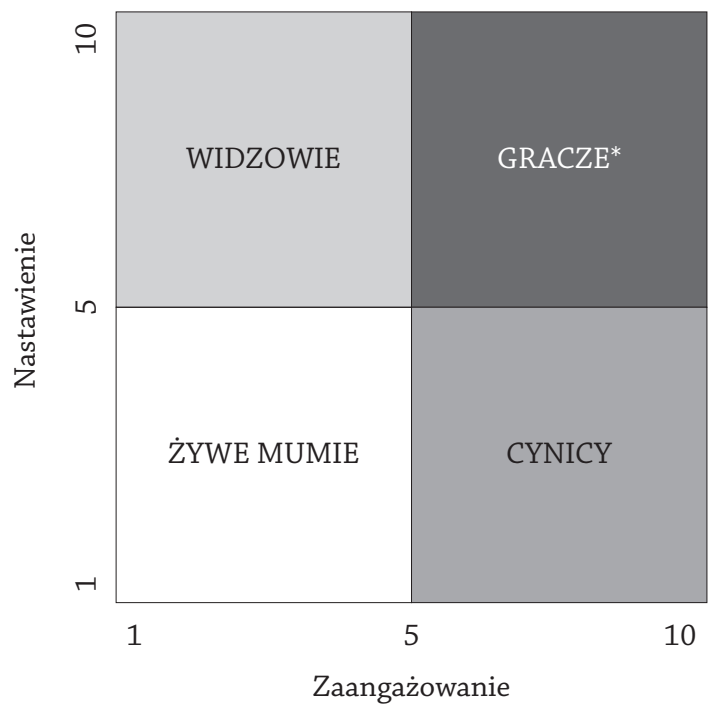

Źródło: opracowanie własne.

Średni wskaźnik „osobistego wkładu” wyniósł 45,70, co wskazuje na to, że badani studenci dysponują jeszcze bardzo dużym potencjałem, którego z różnych powodów nie wykorzystują (maksymalna wartość wskaźnika to 100). Wśród najczęstszych przyczyn braku zaangażowania w pracę zespołową respondenci wymienili: brak chęci współpracy z konkretnymi członkami zespołu, brak zaangażowania pozostałych członków zespołu, co demotywuje do większego angażowania się w działania grupy, brak czasu, niechęć do pracy w nieznanej grupie, konflikty pomiędzy członkami zespołu, brak dobrej komunikacji pomiędzy członkami zespołu, lenistwo, trudny charakter, osobiste problemy $\mathrm{i}$ inne zobowiązania, problemy w nawiązywaniu kontaktów z innymi (niewystarczające umiejętności 
interpersonalne, nieśmiałość), brak wspólnego celu, realizacja nieinteresującego tematu, brak ambicji u pozostałych członków grupy, konflikt z liderem zespołu, brak odpowiedniej motywacji ze strony wykładowcy (nauczyciela przedmiotu), brak pozytywnych efektów współpracy, dominowanie niektórych członków grupy, zbyt mała wiedza i umiejętności przy realizacji danego zadania (projektu).

Tym, co przeszkadza badanym studentom $\mathrm{w}$ większym angażowaniu się w rozwój swoich kompetencji zawodowych (w tym społecznych), jest m.in.: lenistwo, brak czasu, brak motywacji, zmęczenie, trudności finansowe, wątpienie we własne możliwości, poczucie braku perspektyw, brak sprecyzowanych pasji i zainteresowań, małe ambicje, trudności w nauce.

Respondenci planujący w przyszłości założenie własnej działalności gospodarczej rozważają swoją aktywność w następujących obszarach: transport - międzynarodowe przewozy ładunków, sprzedaż, spedycja, transport śródlądowy, gastronomia i catering, serwis sprzętu elektronicznego, mechanika pojazdów, zaopatrywanie klubów sportowych, handel odzieżą, branża TSL, branża IT, handel i serwis rowerowy, sprzedaż internetowa, sprzedaż samochodów, prowadzenie firmy budowlanej. Najczęściej powtarzającymi się obszarami dla prowadzenia własnej działalności była aktywność w branży TSL, co jest naturalne dla studentów kierunku Logistyka.

\section{Podsumowanie}

Przyjęta przez autorkę hipoteza badawcza została pozytywnie zweryfikowana. Potwierdziło się przypuszczenie, że przeprowadzenie badań ankietowych zgodnie z proponowaną metodyką umożliwi przygotowanie stosownych rekomendacji, dotyczących programów kształcenia na uczelniach, które pragną aktywnie kształtować wśród swoich studentów postawy przedsiębiorcze, w tym świadomość potrzeby angażowania się w proces doskonalenia kompetencji zawodowych (w tym społecznych). Zaproponowana przez autorkę metodyka badawcza umożliwia m.in. poznanie opinii (samooceny) studentów na temat ich:

- odpowiedzialności za swój rozwój i przygotowanie do wykonania zawodu,

- stopnia zaangażowania w rozwój swoich kompetencji zawodowych i osobistych,

- postaw przedsiębiorczych, związanych z podejmowaniem samodzielnych decyzji,

- świadomości, dotyczącej roli doświadczenia zawodowego w kształtowaniu praktycznych umiejętności,

- gotowości do podejmowania ryzyka w celu rozwoju swoich kompetencji, 
- Świadomości związanej z koniecznością angażowania się w proces poszerzania i pogłębiania wiedzy oraz zdobywania praktycznych umiejętności, w tym znaczenia realizowanych praktyk zawodowych,

- stopnia kreatywności i niestandardowego podejścia podczas realizowanych zadań (w tym swojego rozwoju),

- dodatkowych wysiłków na rzecz zdobycia doświadczenia zawodowego (np. podejmowania się pracy zarobkowej podczas studiów),

- świadomości, iż standardowy tok kształcenia może się okazać niewystarczający dla znalezienia interesującej pracy (ewentualnie prowadzenia własnej działalności gospodarczej),

- stopnia zaangażowania się $\mathrm{w}$ prace zespołowe (realizowane na uczelni i poza nią), w tym nastawienia (postaw) dotyczących realizowanych prac zespołowych.

Analiza wyników badania ankietowego pozwala na rozpoznanie grupy badawczej pod względem konkretnych postaw przedsiębiorczych oraz stopnia angażowania się w rozwój własnych kompetencji zawodowych (w tym społecznych) - zagadnień tych dotyczy część druga formularza. Zdaniem autorki, pewnym czynnikiem motywującym dla respondentów może być wypełnienie części trzeciej ankiety, w której studenci są proszeni o samoocenę zarówno zaangażowania (energii) w pracę zespołową, jak i swojego nastawienia (podejścia). Relatywnie „niskie” wyniki samooceny w sposób naturalny zmuszają bowiem do pewnej refleksji nad przyczynami takiego stanu rzeczy. Wykorzystując zaproponowane narzędzie badawcze, można rozpoznać wymieniane przez respondentów najczęstsze przyczyny braku angażowania się w samorozwój, a także pracę zespołową - informacje te można pozyskać z analizy wyników pochodzących z części trzeciej formularza.

Podsumowując przeprowadzone badanie, można stwierdzić, że zdecydowana większość respondentów ma wysoką świadomość znaczenia i roli postaw przedsiębiorczych w rozwoju własnych kompetencji i osiągnięciu sukcesu na rynku pracy. Jednakże świadomość ta $\mathrm{w}$ relatywnie niewielkim stopniu przekłada się na konkretne postawy i działania. Studenci raczej niechętnie podejmują ryzyko i dodatkowy wysiłek na rzecz własnego rozwoju. Zbyt często wykazują bierną postawę, oczekując na propozycje ze strony np. wykładowców. Chętnie uczestniczą w wizytach studyjnych, targach, warsztatach, ale nie angażują się w ich organizowanie ${ }^{4}$. Częstą wymówką jest brak czasu, nieśmiałość, lenistwo i mała wiara w swoje możliwości. Jak więc przełamać te opory i zachęcić studentów do większej aktywności?

4 Wyniki prezentowanego badania pokrywają się z przeprowadzoną w 2014 r. analizą postaw studentów kierunku Logistyka wobec pracy (Detyna, 2014). 
Zdaniem autorki, informacje pozyskane $z$ pilotażowego badania ankietowego (zgodnie z zaproponowaną metodyką) mogą zostać wykorzystane jako inspiracja dla osób przygotowujących programy kształcenia w szkołach wyższych (zwłaszcza na kierunkach o profilach praktycznych), tak aby odpowiadały na współczesne wyzwania rynku pracy oraz potrzeby studentów. Opracowując koncepcję kształcenia, warto rozważyć zwiększenie liczebności próby badawczej oraz przeprowadzenie uzupełniających badań wśród interesariuszy np. w postaci wywiadów zogniskowanych oraz grupowych. Cenną konkluzją jest fakt, że zaproponowane badanie ankietowe pozwala na prezentację graficzną wyników w postaci oddziałującej na wyobraźnię studentów „macierzy zaangażowania” w prace zespołowe, które są szczególnie istotne podczas prowadzenia każdej działalności gospodarczej. Niezwykle cenne, zdaniem autorki, są rekomendacje wskazane przez studentów dla uczelni, które chcą kształtować wśród studentów postawy przedsiębiorcze. I tak, wśród aktywności oczekiwanych przez respondentów (studentów studiujących na kierunku o profilu praktycznym) są m.in.:

- planowanie i realizacja większej liczby zadań praktycznych, które rozwijają konkretne umiejętności (zwłaszcza oczekiwane na rynku pracy), dbanie o jakość realizowanych zajęć praktycznych (ćwiczeń, laboratoriów, praktyk zawodowych),

- umożliwianie pracującym studentom kształcenia w formie indywidualnej organizacji studiów (większa elastyczność w tym zakresie),

- organizowanie częstych spotkań z przedstawicielami środowiska społeczno-gospodarczego, z uznanymi liderami (przywódcami), zapraszanie na wykłady i ćwiczenia praktyków, częste organizowanie wizyt studyjnych do przedsiębiorstw,

- inwestowanie w rozwój zawodowy pracowników naukowo-dydaktycznych, prowadzących zajęcia ze studentami (zwłaszcza zajęcia praktyczne),

- wprowadzanie nowych metod i narzędzi kształcenia, które prowokowałyby i zachęcały studentów do kreatywności i niestandardowego myślenia (np. konwersatoriów, prac projektowych, zespołowych, rozwiązywania konkretnych problemów - studiów przypadków),

- organizowanie kursów i dodatkowych zajęć (oczekiwanych przez studentów), certyfikowanych szkoleń (potwierdzających osiągnięcie konkretnych umiejętności),

- stałe inwestowanie w infrastrukturę (np. wyposażenie pracowni komputerowych), aby umożliwiała zdobycie kompetencji oczekiwanych na rynku pracy,

- organizowanie studiów dualnych, które stanowiłyby dla studentów realną szansę na podjęcie po studiach pracy w wybranym przez siebie przedsiębiorstwie, 
- większe propagowanie wśród studentów prowadzenia własnej działalności gospodarczej (realizowanie $\mathrm{w}$ ramach programu kształcenia przedmiotów przygotowujących studentów do takiej aktywności), dbanie o poziom zajęć z zakresu ekonomii, organizacji i zarządzania,

- organizowanie płatnych (dodatkowych) praktyk zawodowych i staży,

- zachęcanie studentów do udziału w konkursach dotyczących wiedzy i umiejętności w danej branży,

- rozwijanie wśród studentów kompetencji społecznych (związanych z komunikacją, radzeniem sobie w sytuacjach stresujących itp.).

Oczekiwania te doskonale wpisują się w strategie rozwoju wielu uczelni, w tym PWSZ AS, której misja jest związana z kształceniem na potrzeby lokalnego i regionalnego rynku pracy (Detyna, 2013c). Warto zatem, aby na rzecz kształtowania wśród studentów postaw przedsiębiorczych oraz większego angażowania się $\mathrm{w}$ proces doskonalenia kompetencji zawodowych uruchomić konkretne działania (Chrabąszcz, 2011; Fafaliou, 2012; Detyna, 2013a; Szerląg, 2015; Łuczka, Rembiasz, 2016; Maresch i in., 2016). Być może należy zweryfikować programy kształcenia oraz karty poszczególnych przedmiotów (tzw. sylabusy). Korzystne w kontekście opisywanego problemu mogłoby się stać wzbogacenie zajęć (zwłaszcza praktycznych) o różnorodne (wyzwalające kreatywność) metody i narzędzia dydaktyczne. Sposobem na rozwój kompetencji społecznych (w tym interpersonalnych) mogą być przykładowo: prace (projekty) zespołowe, rozwiązywanie konkretnych (występujących realnie) problemów (case study), wizyty studyjne, spotkania z liderami i przedstawicielami środowiska społeczno-gospodarczego, praktyczne warsztaty, burze mózgów (sesje pomysłowości), debaty oksfordskie, konwersatoria, organizowanie konferencji, spotkań, udział w konkursach, targach branżowych, pracy itp. Niezwykle cennym doświadczeniem dla studentów, zdaniem autorki, jest aktywne działanie w ramach kół naukowych, samorządów studenckich oraz innych organizacji (Detyna, 2015). Cennym dopełnieniem oferty edukacyjnej świadczonej przez uczelnie prowadzące kierunki o profilach praktycznych byłyby niewątpliwie takie inicjatywy, jak płatne praktyki, staże oraz studia dualne. Działania te mogłyby zachęcić chociaż pewną liczbę studentów do podjęcia dodatkowego wysiłku na rzecz rozwoju postaw przedsiębiorczych (Kabaj, 2012; Detyna, 2016). 


\section{Bibliografia}

Badania rynku edukacji wyższej i kształcenia ustawicznego na terenie Dolnego Śląska. Raport podsumowujacy badania realizowane $w$ ramach projektu „Obserwatorium Dolnośląskiego Rynku Pracy i Edukacji” (2013). Wrocław: Wydawnictwo DWUP. http://dwup.pl/leonardo/pliki/OBSERWATORIUM.pdf (27.07.2017).

Chrabąszcz, K. (2011). Przedsiębiorczość akademicka - drogą do sukcesu absolwentów uczelni wyższych. Zeszyty Naukowe Małopolskiej Wyższej Szkoły Ekonomicznej $w$ Tarnowie, 18(1), 197-208.

Dąbrowska, K., Skowron, M. (2015). Porównanie postaw przedsiębiorczych studentów studiów ekonomicznych, społecznych i humanistycznych. Annales. Etyka w Życiu Gospodarczym, 18(3), 121-131.

Detyna, B. (2015). Aktywność naukowa studentów PWSZ im. Angelusa Silesiusa na przykładzie KN Młodych Logistyków „Just in Time” (lata 2009-2015). W: S. Bielawska (red.), Nowa Kronika Wałbrzyska, t. 3. Wałbrzych: Fundacja „MUSEION”, 121-142.

Detyna, B. (2014). Analiza postaw studentów kierunku logistyka wobec pracy. W: J. Szołtysek, B. Detyna (red.), Logistyka. Współczesne wyzwania, nr 5. Wałbrzych: Wydawnictwo Uczelniane PWSZ AS w Wałbrzychu, 21-42.

Detyna, B. (2013a). Profile kształcenia na kierunku logistyka - nowe wyzwania stojące przed uczelniami wyższymi. Logistyka, 1, 67-71.

Detyna, B. (2013b). Realizacja praktyk zawodowych przez studentów studiów inżynierskich kierunku logistyka - ocena i oczekiwania pracodawców. W: J. Szołtysek, B. Detyna (red.), Logistyka. Współczesne wyzwania, nr 3. Wałbrzych: Wydawnictwo Uczelniane PWSZ AS w Wałbrzychu, 145-157.

Detyna, B. (2013c). Rola uczelni wyższych w budowaniu marki i promocji Regionu Wałbrzyskiego. W: K. Malicki (red.), Marka i promocja jednostek terytorialnych. Dylematy i wyzwania współczesności. Rzeszów: Uniwersytet Rzeszowski, 203-218.

Detyna, B. (2016). Studia dualne jako źródło potencjalnych korzyści dla różnych grup interesariuszy, w tym rozwoju postaw przedsiębiorczych i kompetencji zawodowych studentów. Edukacja Ekonomistów i Menedżerów. Problemy. Innowacje. Projekty, 2(40), 81-98.

Drucker, P. (1992). Innowacja i przedsiębiorczość. Warszawa: PWE.

Fafaliou, I. (2012). Students propensity to entrepreneurship: An exploratory study from Greece. International Journal Innovation and Regional Development, 4(3-4), 293-311.

Fundacja Inicjatyw Młodzieżowych Nowoczesne Zarządzanie Biznesem (2016). Start na rynku pracy, skrót raportu. Warszawa, 2-25.

Goleman, D. (2015). Inteligencja społeczna. Poznań: Dom Wydawniczy REBIS.

Gordon, M.E. (2009). Przedsiębiorczość. Gliwice: Helion. 
Górniak, J. (red.). (2015). Polski rynek pracy - wyzwania i kierunki działań na podstawie badań Bilans Kapitału Ludzkiego 2010-2015. Warszawa: Polska Agencja Rozwoju Przedsiębiorczości.

Instytut Badań Edukacyjnych (2014). Monitorowanie losów absolwentów uczelni wyższych z wykorzystaniem danych administracyjnych Zakładu Ubezpieczeń Społecznych. Raport końcowy. Warszawa.

Kabaj, M. (2012). Wpływ systemów kształcenia zawodowego na zatrudnienie i bezrobocie młodzieży. Projekt programu wdrożenia dualnego systemu kształcenia zawodowego $w$ Polsce. Warszawa: IPiSS.

Łuczka, T., Rembiasz, M. (2016). Badanie postaw przedsiębiorczych studentów - wybrane aspekty teoretyczne i empiryczne. Horyzonty Wychowania, 15(34), 27-46.

Maresch, D., Harms, R., Kailer, N., Wimmer-Wurm, B. (2016). The impact of entrepreneurship education on the entrepreneurial intention of students in science and engineering versus business studies university programs. Technological Forecasting \& Social Change, 104, 172-179.

Marszałek, A. (2012). Analiza postaw przedsiębiorczych wśród studentów. e-mentor, 3(45). http://www.e-mentor.edu.pl/artykul/index/numer/45/id/932 (19.01.2017).

Miller, D. (2010). Zespoły. Warszawa: PWE.

Narodowe Centrum Badań i Rozwoju (2014). Analiza kwalifikacji i kompetencji kluczowych dla zwiększenia szans absolwentów na rynku pracy. Warszawa. http:// www.uj.edu.pl/documents/102715934/001bcfee-7b59-4983-9eaf-2ca7adbc7ad2 (27.07.2017).

PARP (2016). Raport kończący cykl badań w ramach projektu Bilans Kapitału Ludzkiego (2010-2015). https://bkl.parp.gov.pl/ (26.07.2017).

Patrz w przyszłość. Dolnoślqzacy w programie Horyzont 2020 (2015). Wrocław: Wydawnictwo Politechniki Wrocławskiej.

Roos, G.H. (2005). Trump strategies for real estate. Hoboken: John Wiley \& Sons.

Skała, A. (2015). Przedsiębiorczość - wyzwanie dla edukacji. W: A. Pastuła, J. Majczyk, M. Darecki (red.), Przedsiębiorczość: jednostka, organizacja, kontekst. Warszawa: Wydawnictwo Naukowe Wydziału Zarządzania Uniwersytetu Warszawskiego, 11-31.

Szerląg, A. (2015). Kompetencje społeczne jako atrybut edukacji dla społeczeństwa wiedzy w edukacji akademickiej i w oczekiwaniach pracodawców. W: Ż. Kaczmarek (red.), Interdyscyplinarność i transdyscyplinarność $w$ procesie kształcenia $w$ szkolnictwie wyższym. Pytania o efektywność kształcenia. Toruń: Wydawnictwo Adam Marszałek \& Uniwersytet Medyczny im. Piastów Śląskich we Wrocławiu, 29-51. Związek Banków Polskich (2016). Portfel studenta - raport. Warszawa. 


\section{Summary}

\section{Measurement and Evaluation of Entrepreneurial Attitudes and Student Involvement in Process of Professional Competence Improvement - Methodical Proposals}

Presentation of methodical proposals, which refers to the measurement and evaluation of entrepreneurial attitudes and student involvement in the process of professional competence improvement is the goal of this article. The author presents the results of a pilot study carried out among students of the A. Silesius University of Applied Sciences in Wałbrzych, which used to verify the developed tool - the survey form. Research results can be used as an inspiration for those preparing training programs in higher education institutions, in such a way as to respond to the contemporary challenges in the labor market and the needs of students. Surveys allowed for graphic presentation of results in the form of a matrix of student involvement in the work team, also a creation of a list of the most common reasons for the lack of student involvement in both group work and in the self-development.

Keywords: entrepreneurial attitudes, measurement and evaluation of entrepreneurial attitudes, students, professional competence, improving professional skills

\section{Dr Beata Detyna}

Doktor nauk ekonomicznych w zakresie nauk o zarządzaniu, w specjalnościach: zarządzanie jakością w sektorze usług, ocena jakości, logistyka usług. Wykładowca przedmiotów związanych z ekonomią, organizacją i zarządzaniem, kierowaniem zespołami ludzkimi, a także logistyką w usługach oraz zarządzaniem jakością. Obecnie Pełnomocnik Rektora ds. Współpracy z Otoczeniem Społeczno-Gospodarczym oraz Dyrektor Instytutu Przyrodniczo-Technicznego w Państwowej Wyższej Szkole Zawodowej im. Angelusa Silesiusa w Wałbrzychu. Zainteresowania naukowe: problematyka pomiaru i oceny jakości w środowisku szkół wyższych oraz zakładów opieki zdrowotnej. Beneficjentka grantów naukowych Prezydenta Miasta Wałbrzycha (2008, 2010), nagrody indywidualnej MNiSW za osiągnięcia organizacyjne (2015), a także stypendium Santander Universidades (2016). Autorka ponad 90 recenzowanych publikacji (w tym pięciu książek). 